\begin{abstract}
The aim of this paper is to focus, within Adam Smith's system of thought, on the various aspects of the twofold link between the accumulation of capital and the demand for labor, on the one hand, and between an increasing population and increasing wages, on the other. This link is examined, first, in the light of the relationship between the principles of self-interest and competition; and, secondly, in support of the possibility (neglected by Smith) that the long-run supply of labor may fall short of the long-run demand for it. The paper's main argument is that this possibility is peacefully implemented in advancing economies by the "uniform, constant, and uninterrupted effort of every man to better his condition" which lies behind a continuous process of capital accumulation (including technical progress) along with the birth control techniques so widely used in our times.

* Department of Economics and Management. University of Padova.

Contact: ferdinando.meacci@unipd.it
\end{abstract}

This "preprint" is the peer-reviewed and accepted typescript of an article that is forthcoming in revised form, after minor editorial changes, in the Journal of the History of Economic Thought (ISSN: 1053-8372), issue TBA. Copyright to the journal's articles is held by the History of Economics Society (HES), whose exclusive licensee and publisher for the journal is Cambridge University Press. (https://www.cambridge.org/core/journals/journal-of-thehistory-of-economic-thought) This preprint may be used only for private research and study and is not to be distributed further.

The preprint may be cited as follows:

Meacci, Ferdinando. "The Link Between Capital Accumulation and Increasing Wages in an Updated Version of Smith's Theory Of Population". Journal of the History of Economic Thought (forthcoming). Preprint at SocArXiv, osf.io/preprints/socarxiv 


\section{THE LINK BETWEEN CAPITAL ACCUMULATION AND INCREASING WAGES IN AN UPDATED VERSION OF SMITH'S THEORY OF POPULATION ${ }^{1}$}

\section{Introduction.}

The system of thought of the Wealth of Nations (WN from now onwards) can be split into two ideal parts: one is focused on the theory of value and distribution (Book I), the other on the theory of capital and growth (Book II). While the first part is built on the twofold view of value as labor embodied and labor commanded, the second part is built on the twofold view of capital from the standpoint either of its individual owners or of the whole society. The two parts are linked together by the interactions between the principles of self-interest and competition, on the one hand, and between the process of capital accumulation and the future of wages, on the other ${ }^{2}$.

The aim of this paper is to focus on these interactions in an attempt to highlight the long-run relationships between the accumulation of capital and the demand for labor, on the one hand, and between the increase of population and the supply of labor, on the other. This will be done by singling out, first, the containment of the principle of self-interest (which, if pushed to excess, would lead all men to try to "reap where they never sowed", $W N$, I.vi.8) by the principle of

\footnotetext{
${ }^{1}$ A different version of this paper was presented under a different title at the Annual Meeting of the International Adam Smith Society, Viña del Mar, Chile, January 12-13, 2018. I wish to thank the discussants and colleagues who have contributed to a number of subsequent modifications of my earlier presentation. I wish to thank in particular the referees of this journal for their useful criticisms and comments which have enabled me to add some further improvements to my previous draft.
}

${ }^{2}$ The term wages will be used throughout this paper in the sense of real (rather than money) wages and, even more precisely, of wages per man (rather than of aggregate wages). See, on this and related issues, Cannan ([1917] 1967, chaps. VII-VIII). 
competition; and, then, the containment of the increase of population by the "uniform, constant, and uninterrupted effort of every man to better his condition" ( $W N$, II.iii.31).

This aim will be pursued in six different steps. The first will consist in moving from the sentiments of sympathy and propriety discussed by Smith in his Theory of Moral Sentiments (TMS from now onwards) to the principles of self-interest and competition as focused upon in his Wealth of Nations (section 1). The second step will consist in moving from these principles to the determination of the exchange value of labor (section 2) while the third step will consist in moving from the impact of the accumulation of capital on the "productive powers of labour" to the resulting possible increase of that exchange value (section 3). The fourth step is carried out in section 4 and constitutes the core of the paper. This step consists in providing three partial supports and one final adjustment of Smith's theory of population in the light of the reproductive behavior of human beings in modern societies. As argued in the following section 5, this adjustment is needed for moving towards the link between the accumulation of capital (in its widening and deepening directions) and the long-run increase of wages as observed in the history of modern societies.

The paper's conclusion is that, when the conditions under discussion are met, the accumulation of capital reappears as the ultimate cause of a long-run increase of wages in spite not only of the counter-interested behavior of "masters and manufacturers"; but also of the tendency of population to increase beyond the means of its subsistence. This unexpected outcome is eventually regarded as just one of the "many other cases" alluded to by Smith in the frequently misunderstood passage on the individual who, though engaged in international trade exclusively for his own profit, "is led by an invisible hand to promote an end which was no part of his intentions" $(W N, \text { IV.ii.9 })^{3}$.

\footnotetext{
${ }^{3}$ Reasons of space will prevent us from focusing not only on the details of the invisible-hand issue (starting from the differences between the role assigned to it in a single passage of the Theory of Moral Sentiments, IV.i.10-11, and the more crucial role it plays in $W N$ up to the large number of diverging interpretations provided so far); but also on the long series of publications on many other
} 


\section{From sympathy and propriety to self-interest and competition.}

To understand the roles assigned to self-interest and competition in the Wealth of Nations, it may be useful to start from two shifts that keep apart this work from Smith's previous work The Theory of Moral Sentiment (TMS from now onwards) ${ }^{4}$. While one of these shifts goes from the sentiment of sympathy to the principle of self-interest, the other goes from the propriety of that sentiment to the principle of competition between different individuals. Leaving aside a detailed discussion of these shifts $^{5}$, this paper will start by highlighting the different roles assigned in $W N$ to the two principles mentioned above. The first thing worth noticing in this connection is that, despite the important role assigned in $W N$ to the principle of competition and despite the fact that the term self-interest is there used just once and is replaced by the term self-love only twice (see V.I.191 and I.2.2), the role assigned in the same work to the principle of self-interest is even more crucial than the role assigned in it to the other principle. The reason lies in the fact, highlighted by Smith in the first aspects of Adam Smith's theory in recent decades. Among these publications it is here possible to remember, in addition to those that will be cited below, the works by Skinner and Wilson (1975), Wilson and Skinner (1976), O’ Driscoll (1976), Cunningham Wood (1984), Skinner (1996), Haakonssen (2006), Montes and Schliesser (2006), Young (2009), Berry, Paganelli and Smith (2013).

${ }^{4}$ It is known that the similarities and dissimilarities between these two works have given rise to a series of interpretations and controversies known in the literature as Das Adam Smith Problem. For a detailed discussion of this problem, see Raphael and Macfie (1976), Otteson (2002), Montes (2004), Fleischacker (2004), Evensky (2005), and other authors mentioned in these publications.

${ }^{5}$ For a brief discussion of these issues, see for instance Wilson (1976), Hollander (1977), Heath (2013) and Sen (2011). For a more complex discussion of the same issues, see the works mentioned in the previous footnote. 
place, that the principle of self-interest is so strong that it may affect the implementation of the other principle along two completely different directions. For, while in one of these directions the principle of self-interest is used to reinforce the other principle in the process of production of national wealth, in the other completely different direction it rather serves to support the "abuses" and "monopolizing spirit" of merchants and manufacturers (not to speak of the "capricious ambition" of kings and ministers) when they try to persuade the public that "the private interest of a part, and of a subordinate part of the society, is the general interest of the whole" (IV.iii.38; I.x.80) ${ }^{6}$.

\section{From self-interest and competition to the labor market and the value of labor.}

The shift from the concepts of sympathy and propriety to the concepts of self-interest and competition is implicitly brought to the fore by Smith himself when stating, right at the beginning of $W N$, that "the annual labour of every nation is the fund which originally supplies it with all the necessaries and conveniences of life". This statement implies that labor plays in the $W N$ a more crucial role than even sympathy does in $T M S^{7}$. It must however be noted that this role is somewhat

${ }^{6}$ This paper will be focused on the first direction only. For a brief view of the two directions, see Stigler (1971) and his concluding remark that "the high priest of self-interest, like all other high priests, had a strong demand for sinners“. See also Rosenberg (1975) who moves along the same lines when distinguishing the behavior of individual capitalists from the outcomes of "competitive capitalism". For a view of self-interest as affecting the economy along the second direction, see Paganelli (2008). For the role of competition between self-interested individuals as an engine for turning the second direction into the first, see O’Donnell (1990, chap. 4).

7 This role is highlighted in other famous passages such as the one on labor as "the first price, the original purchase-money that was paid for all things", or the one according to which "it was not by gold or by silver, but by labour, that all the wealth of the world was originally purchased" ( $W N$, I.v.2; see also I.xi.e.34). 
obscured when, in the context of his theory of value, Smith comes to the further statement that "equal quantities of labour, at all time and places, may be said to be of equal value to the labourer"; and, even more so, when he moves on to the all-encompassing conclusion that "labour, therefore, never varying in its own value, is alone the ultimate and real standard by which the value of all commodities can at all times and places be estimated and compared" (WN, I.v.7; italics added).

The ambiguities of these passages lie, to begin with, in the term "value" which is intended, in the first statement, as the constant "value to the labourer" of equal quantities of his own labor; whereas, in the following statement, it is intended as the varying "value of all commodities" as products of labor (which in turn is said to be "never varying in its own value"). These ambiguities have not been stressed in the literature as much as they would deserve.

Concerning the first ambiguity, it must be noted that the verbs "to purchase" and "to acquire" are used in that chapter as if they represented the purchase of something by one set of individuals from another. These expressions, however, should rather to be intended as metaphors serving to highlight the vertically-integrated process (as it is called in modern literature) by which the final output of today reappears as the result of the total labor employed in a near or a distant past. This is silently admitted by Smith himself when, in one of his sentences quoted in the previous footnote, the expression "wealth of the world" (not, therefore, the wealth of a particular country, individual or group of individuals) is said to be "originally purchased" by labor, an expression that at this point must be understood exclusively in the sense that it was originally produced by labor.

Concerning the other ambiguities, it must be noted that the term value is used in the statements above in the sense of the "toil and trouble" experienced by the (average) laborer as the (negative) use value of his labor from his own standpoint; but also in the sense of the (positive) exchange value of one product of labor in terms either of a different product, or (in the form of wage-goods) of labor itself. Smith's ambiguities reach here a climax in that his wording obscures not only his initial distinction between the elementary concepts of value in use and value in exchange, but also his further and more advanced distinction between the concepts of labor 
"embodied" and labor "commanded" which lie at the root of his theory of value; not to speak of his less known distinction between "work done" and "work to be done" as highlighted by Smith himself in his public mourning example (WN, I.vii.19). For it must here be noted that one thing is to exchange a product of labor for a different product (or work done in a specific form for work done in a different form, or even, in Marx's own terms, one form of dead labor for a different form), another thing is to exchange some products of labor (wage goods) for labor as living labor in a work-to-be-done context. Furthermore, one thing is to exchange either a product of labor for a different product in the "early and rude state of society", another thing is to exchange it in a more advanced state (once division of labor and capital accumulation have taken place). For the wage goods here exchanged for the labor available this year are not only the result of the labor employed in a recent or more distant past; they are also the condition for the labor of this year to promote the reproduction of commodities, including wage goods, to be consumed in the next or in the following years. Net of the problems created by rent, this calls for splitting the exchangeable value of the commodities produced this year into the share determined by the amount of (direct and indirect) labor embodied in each of them and the share determined by the (greater) amount of labor that these commodities will command, or be exchanged for, in the form either of work done (dead labor) or of work to be done (living labor) in the years to come . $^{8}$

3. From the labor market and the value of labor to the accumulation of capital and the increasing "productive powers of labour".

The concept of labor as the original source of value, however ambiguously presented by Adam Smith, plays in $W N$ a more explicit role than the role assigned in it to laborers as the potential

\footnotetext{
${ }^{8}$ For a more detailed treatment of these distinctions, starting from the one between the command of living labor (which includes only wages) and of dead labor (which includes, net of rent, only wages and profits), see Meacci (2012, 2017).
} 
receivers of the benefits resulting from the increase of national wealth. This second role, however, deserves to be highlighted more than it is usually done in the current literature. This can be done by examining the arguments provided in $W N$, Book I, and more particularly in its chapter VIII, Of the Wages of Labour, in connection with the arguments of Book II, and more particularly of its chapter III, Of the Accumulation of Capital, or of Productive and Unproductive Labour. The link between these two sets of arguments will be discussed below in the light of the process of capital accumulation as an engine activated by "masters and manufacturers" exclusively in the light of their own self-interest.

Leaving aside the important issues, announced by Smith at the beginning of chapter VIII, Book I, of the shares of output (profit and rent) not appropriated by (distributed to) laborers, and leaving also aside Smith's introductory discussion of the ineffective combinations of laborers as "desperate men" struggling for a rise of their wages, we will here focus exclusively on the arguments concerning the circumstances that enable laborers to experience a repeated rise of wages in spite of their masters' potential combinations against them. Here Smith implicitly resorts to the principle of demand and supply in order to explain both the causes of an increasing demand for labor and its effects on the increasing supply of it. While, with regard to the causes, they are traced to a continuous increase of the funds destined for the payment of wages, with regard to the effects these are traced, in a short-run context, to the possible increase of the "liberal reward of labour" and, in a long run context, to a continuous increase of population.

We will focus below on the causes and consequences of the latter incras. For now our analysis will be focused only on two different effects of the increasing demand for labor: one of these effects consists in an increase in the "productive powers of labour" ( $W N$, I.viii.3-5) while the other consists in an increase in the "industry of the common people" (WN, I.viii.44). However similar these two effects may appear to be, they have a completely different relevance: while the latter effect is limited by the restrictive attitude of laborers concerning the "toil and trouble" of their labor, the former effect has an unlimited relevance within Smith' theory of capital accumulation, on the one 
hand, and the resulting increase of wages, on the other. Three remarks deserve to be made in this connection.

First. One remark concerns the term "industry" used by Smith with regard to the second effect. This term is used, at least in the passage just mentioned, not in today's sense of a particular branch of production but in Smith's own sense of the "human quality" (industriousness in modern terms) by which a laborer becomes more "active, diligent, and expeditious"( $W N$, I.wiii.44) ${ }^{9}$. Now if the liberal reward of labor is regarded, as Smith does, as a source of industry in this sense, it cannot be regarded as the source of an increase in the productive powers of labor beyond the limits set by that human quality. For, once these limits have been reached, the productive powers of labor can be increased only by resorting to another more powerful and enduring factor. This is mentioned at the end of Smith's chapter on wages in support of his rejection of the idea that an increase of wages, by increasing the price of many commodities, would result in a reduction of their consumption (and therefore of the demand for the labor employed in their reproduction). Here his argument runs as follows:

"The same cause, however, which raises the wages of labour, the increase of stock, tends to increase its productive powers, and to make a smaller quantity of labour produce a greater quantity of work" so that "there are many commodities, therefore, which, in consequence of these improvements, come to be produced by so much less labour than before, that the increase of its price is more than compensated by the diminution of its quantity" ( $W N$, I.viii.57; see also I.xi.240).

\footnotetext{
${ }^{9}$ On the prevailing meaning of the term "industry" as a human quality or a quality of human labor, see an unlimited number of passages in $W N$, starting from the one on the "employers of industry" $(W N$, I.8.53) and the one on every man who "endeavours to supply by his own industry his own occasional wants as they occur" ( $W N$, II.i.1), and so on and on up to the crucial passage of Book II where "industry" is contrasted with "idleness" ( $W N$, II.iii.12).
} 
This argument provides one of the best insights as well as one of the best visions of the $W N^{10}$. This insight will be discussed in the following sub-section while the resulting vision will be highlighted in the third and final sub-section.

Second. A further remark is whether what is called, in the passage just quoted, an "increase of stock" does, or does not, coincide with what had been called, in some previous passages of the same chapter, an "increase of revenue and stock". This issue can be introduced by the following questions: is it by chance that the term "revenue" is dropped by Smith in the passage just quoted? Or are these two expressions consistent with the different sets of arguments they are intended to support? If one reads chapter VIII, Book I, having in mind what is argued in chapter III, Book II, one can realize that the jargon adopted by Smith in the previous chapter is consistent with the fact that the demand for labor is there dealt with regardless of whether it comes from the "expenditure of revenue" or from the "employment of capital". For what is there under discussion is whether the demand for labor, however generated, increases by more or less than population (usually intended in $W N$ as a proxy for labor supply).. Here Smith abstains from going deeper into the difference between these two increases for what he is here interested in is only that, if the funds lying behind the demand for labor "have continued for several centuries of the same, or very nearly of the same extent" (i.e. if these funds do not increase from period to period along with population), then "labourers would be obliged to bid against one another" to get the employment they are looking for ( $W N$, I.viii.24). The fact is that what really matters is not so much whether a country is rich or poor, but whether its wealth is increasing or not from one period to another. And what matters most,

${ }^{10}$ This insight is rendered even better in the Early Draft of $W N$ where Smith's argument is that "in an opulent and commercial society labour becomes dear and work cheap, and those two events [i.e. a diminution in the price of work and an increase in the wages of labor], which vulgar prejudices and superficial reflection are apt to consider as altogether incompatible, are found by experience to be perfectly consistent" ([1776] 1978, p. 567; see also p. 343 and p. 350; italics added). 
when its wealth is increasing, is not whether the whole demand for labor is increasing, but whether it is increasing by more than its supply. Hence the principle of demand and supply here applied to the determination of wages in the long-run context of a changing population. Hence the link between what happens in the labor market of the current period and what will happen in the labor markets of the periods to come. Here the initial conclusion is that an increase in the "funds destined for the maintenance of labor" is needed for wages to increase above the rate "consistent with common humanity". But the final conclusion is that the future of wages will depend on whether these funds will actually increase by more, by as much, or by less than population will do in the same periods ${ }^{11}$.

${ }^{11}$ It must here be noted that the expression "funds destined for the maintenance of labor", used in $W N$, Book I, does not convey the same concept as the expression "funds destined for the payment of productive labor" (italics added) used in Book II. And it must, however, be added that the phenomenon of an increasing population need not coincide (due to changes in the working age and life expectancy) with a corresponding increase in labor supply in spite of Smtih's tendency to neglect this difference. It should also be noted that the term stock is often used in $W N$ as synonymous with the term capital in spite of the fact that, even when this is the case, the term stock reflects the concept of capital in its existence at an instant of time while the "funds destined for the payment of productive labor" rather reflect the concept of capital in its becoming in the course of time, i.e. as the flow of wage-goods exchanged for productive labor and transformed by it into invested capital (as distinct from free capital in Jevons' terminology). For further details on this distinction, see Meacci and Ferlito (2018). For a previous treatment of these issues, see a number of contributions starting from Ricardo (Principles, chap. VIII) and Malthus ([1836] 1986, Book I, chap. IV) up to Cannan ([1917] 1967, chap. IV) and Hollander (1973, chaps. 6-7): See, in particular, Hollander's criticism of Cannan's and Marx's views of capital as a stock rather than as a stock as well as a flow (ibid., chap. 6, n.2). 
Third. The final remark is that Smith's transition within chapter VIII, Book I, from the expression "revenue and stock" to the expression "increase of stock" can in turn be regarded as an introduction to the more crucial transition from the latter expression to the increase of the "productive powers of labour". The important difference between this concept and the concept of "industry" discussed above lies in the fact that, while industry cannot increase beyond the limits set by the length of the working day, the "productive powers of labour" can increase, whatever the length of the working day, beyond the level reached even after the division of labor has been "thoroughly introduced" (WN, II. Introduction. 2). What contributes to increasing the "productive powers of labor" beyond this level is the accumulation of capital as the ultimate, and unremitting, engine for the growth of national wealth ${ }^{12}$. Hence Smith's fundamental insight quoted within the

${ }^{12}$ The role of capital accumulation is what provides a solution to Smith's apparent contradiction between his arguments, in Book I, on the country, such as the China of his times which had acquired the "full complement of riches" and "which could, therefore, advance no further" (to the extent that marriage was there encouraged "not by the profitableness of children but by the liberty of destroying them”) (WN, I.viii.22-24 and I.ix.14-15); and his arguments, in Book II, where the "full complement of riches" implicitly reappears as something that can be overcome by a continuous process of capital accumulation in so far as this involves an enlargement of the extent of the market, the introduction of new machinery, technical progress and increasing returns ( $W N$, I.iii and II.4; see in this connection, to begin with, Young, 1928, and, eventually, section 5 below). This implies that the "full complement of riches" should be rather regarded in Smith's system of thought as an assumption concerning what is a possible, rather than an unavoidable, condition of particular countries, the accumulation of capital being the ultimate force that can turn through periods of adequate length the "declining" into the "stationary" state and (as proved by the history of modern China) the "stationary" into the "progressive" state (if only because, as noted by Hollander, 1973, p. 185 , one thing is a "temporary", another a "permanent", stationariness). Hence the diverging views 
first remark above. For not only does this insight imply a support for the idea that there are circumstances in which an increase of wages may not raise the price of commodities. It also goes further by hinting at the increasing "productive powers of labour" promoted by the accumulation of capital (through the introduction of new machinery and technical progress) as a natural reaction of "masters and manufacturers" to such an increase.

This is one of Smith's most important visions with regard not only to the development of a "great society" but also to the economic history of the world in the centuries following the publication of his work. It also paves the way for a distinction and a relationship that have been introduced only later in the language of economic analysis. These are, in the first case, the distinction between capital widening and capital deepening; and, in the second case, the wage-profit inverse relationship ${ }^{13}$. It is the interaction between these two forms of accumulation as well as between the two directions of this relationship that has made it possible in the past, and will make it possible in the future, to arrange and re-arrange the production and reproduction of "many" commodities at a diminishing labor cost per unit of output in spite of increasing wages or, to use a of the stationary state as a long-run possibility (according to Smith), a long-run necessity (according to Ricardo), and a desirable outcome (according to J. S. Mill).

${ }^{13}$ While such a distinction was highlighted by Hawtrey (1952) in the footsteps of Wicksell's own distinction between the growth of capital "in height" and "in width" (1967 [1934]), the associated relationship, which is implicit in some of Smith's arguments on wages and profits, was developed by Ricardo and has been reproduced in modern times in the direction not only of movements along, but also of shifts of, the downward-sloping curve representing such a relationship (see, for instance, Kurz, 2010). For a discussion of Smith's version of the wage-profit inverse relationship and of the fallacy of composition erroneously attributed to this version, see Sinha (2010). For a further discussion of this relationship and of its links with the competition-of-capitals doctrine, see Meacci (2006). 
still different terminology, in spite of the increasing value of labor in terms of the wage goods exchanged for it $^{14}$.

4. From the accumulation of capital to the growth of population: three partial supports and one final adjustment of Smith's theory

The principle of demand and supply has been discussed above with exclusive regard to the long-run demand for labor. Now the time has come to extend it to the long-run supply of it. This is what Smith does in the middle of chapter VIII, Book I, when dealing with the dynamics of population. The analysis of this dynamics is brought to the fore in the context of the arguments on the liberal reward of labor mentioned above; and, more particularly, in the context of Smith's central thesis that the "demand for men" regulates and determines the "production of men" in different countries of the world (WN, I.viii.40). Some remarks, however, are to be made concerning the correspondence between these passages and what has happened to the condition of laborers in the centuries following the publication of Smith's work.

${ }^{14}$ If one keeps the short-run aspects of these phenomena apart from their long-run implications, it is possible to single out some similarities between this vision and Ricardo's argument (however based it may be on a different theory of the natural price of commodities) according to which "the public" (to be intended as the whole set of consumers) is benefited by machinery in that "these mute agents are always the produce of much less labour than that which they displace" (Principles, chap. I, p. 42). Neither is that vision entirely contradicted when Ricardo, in his later chapter on machinery, develops his new arguments (concerning, in the first part of the chapter, the determination of what appears to be the market price of labor) under the specific assumptions $1^{\text {st }}$ ) that "improved machinery is suddenly discovered, and extensively used"; and $2^{\text {nd }}$ ) that this occurs under conditions of constant savings (ibid., chap. XXXI, p .395). For a most recent focus on the limits assigned by Ricardo himself to his famous chapter on machinery, see Hollander (2019). 
First. After starting with a "but" the sentence on the reproduction of human beings soon after the sentence on the reproduction of "every species of animals" 15 , Smith does admit that the latter kind of reproduction may be typical of the "inferior ranks of people" (as in the case of the "halfstarved Highland woman" who, after generating twenty children, remains with only two alive). But he also seems to introduce the view that this reproductive behavior is destined to change if the demand for labor keeps increasing from period to period. Here the weakness of Smith's arguments lies only in the fact that he leaves unsettled the crucial issue as to whether, once the "combinations of masters" are dissolved and population is increasing, the "liberal reward of labour" will, or will not, increase in the course of time along with a continuous increase in the demand for it. Which implies the more specific issue, announced at the end of subsection 2 of section 3 above, as to whether the rate of increase of the demand for labor will exceed, or remain equal to, the rate of increase of its supply. The settlement of this issue is crucial, as we shall see below, for a final assessment of Smith's vision of the future of wages ${ }^{16}$.

Second. The difference between the reproductive behavior of human beings (lying behind the long-run supply of their labor) and that of "every species of animals" is not highlighted in chapter VIII, Book I, as much as it would deserve. Yet such a difference can be singled out if another

15 "Every species of animals multiplies in proportion to the means of their subsistence, and no species can ever multiply beyond it" (WN, I.viii.39).

16 This is one of the reasons why Cantillon's statement that "men multiply like mice in a barn if they have unlimited means of subsistence" ([1755] 1964, p. 83) cannot properly belong to Smith. Another, and more advanced reason, will be discussed below in this section. For a discussion of why the different rates of growth mentioned above should be assumed (for Smith to be consistent with his more advanced vision of the future of wages) to be unequal (rather than equal) and, indeed, not unequal in the sense figured out by Ricardo, but rather in the opposite sense that the rate of growth of the demand for labor exceeds the rate of growth of its supply, see section 5 below. 
famous passage of Book I is linked to one of the most crucial arguments of Book II. This passage occurs when Smith comes to highlighting an aspect of human behavior which is totally absent in the life of animals. This is the "the propensity to truck, barter, and exchange one thing for another" (WN, I.ii.1). This aspect, however, is more far reaching than Smith's words seem to imply. For the propensity of human beings to truck one thing for another is not confined to an exchange of present for present goods, a form of exchange that prevails (if ever) in the "early and rude state of society". But it also extends itself to the exchange of present for future goods, a more advanced form of exchange pursued by forward-looking individuals in a more advanced society. It is indeed this further form of exchange what supports that great vis medicatrix reipublicae (in Malthus' own words) which is the "uniform, constant, and uninterrupted effort of every man to better his condition" (WN, II.iii.31).

Third. The sentence just quoted is repeatedly used in the $W N^{17}$ and is widely known to its readers $^{18}$. The most detailed presentation of such an effort, however, is put forward when, in the context of the theory of capital set out in Book II, Smith comes to the contrast between the "principle which prompts to expence" and the "principle which prompts to save" (WN, II.iii.28). Now, if one thinks of the adjectives "uniform, constant, and uninterrupted" attached to the term

\footnotetext{
${ }^{17}$ See, in particular, WN, I.viii.44; II.iii.28; II.iii.31; II.iii.36; III.iii.12; IV.v.b.43; IV.ix.28. See also p. 341, n.29, and p. 540, n.32.
}

${ }^{18}$ This expression is also used, though just once, in $T M S$, I.iii.2.i. There is a difference, however, between the sentence "that great purpose of human life which we call bettering our condition", used in $T M S$, and similar sentences repeatedly used in $W N$. For the $T M S$ sentence is used (in consistency with the object of this work as distinct from $W N$ ) not in terms of the exchanges resulting from that "great purpose"; but only in terms of the moral sentiments of the "prudent man" whose parsimony is viewed in TMS (VI.i.11) as an effect of the virtue of prudence, or as one of its applications in the specific field of exchanges of present for future goods between self-interested individuals. 
effort, and if one remembers that this effort is said to be typical of every man (apart from the minority cases of prodigality and misconduct), it is possible to conclude that the propensity to save is a prevailing feature of human beings as forward-looking individuals; and also that, the opposite principle being just a "passion for present enjoyment", the propensity to save may in turn be regarded as a passion for future enjoyment or, in more modern terms, as a result of the time preference by which the future benefits expected by individuals from their current savings will overcome the corresponding sacrifice of their current consumption ${ }^{19}$.

Now, if these arguments are considered in the light of the dynamics of population discussed above, it is possible to conclude that the "uniform, constant, and uninterrupted effort of every man to better his condition" cannot materialize if population were to increase, as Smith seems to imply

19 This aspect of the behavior of human beings, as distinct from other "species of animals", is implied in other passages of $W N$ (such as the one -by which Ricardo was "deeply impressed"- on the unlimited desire of "conveniences and ornaments" versus the desire of food which is limited by “the narrow capacity of the human stomach", see WN, I.xi.c.7; and Ricardo's Principles p. 387). The over two centuries of growth that have followed Smith's work are there to prove that a large number of final goods are exchanged today, in addition to food, for the labor of the "common people". The fact that these wage-goods were, partially or totally, unthinkable in Smith's times strengthens his astonishing conclusion that "the accommodation of an European prince does not always so much exceed that of an industrious and frugal peasant, as the accommodation of the latter exceeds that of many an African king, the absolute master of the lives and liberties of ten thousand naked savages" (WN, I.i.11). This conclusion is regarded by Aspromourgos $(2009,2010)$ as a variant of the "trickle down" phenomenon by which wages increase in modern societies as a result of the process of accumulation of capital in spite of the resulting inequalities in income distribution. The role of this process as a vehicle for the long-run increase of wages has been noted also by Brewer (2010, chap. 11, pp. 178-180) though not to the extent of denying an upper limit to it. 
in chapter VIII, Book I, at the same rate at which the funds destined for its maintenance do. But it must be noted that, for Smith's arguments on the potential increase of population and on that "uniform, constant, and uninterrupted effort" to be consistent with each other, the rate of increase of population must be assumed to fall short of the rate of increase of the funds destined to the maintenance of all its components, i.e. of productive laborers, unproductive laborers; and "those who do not labour at all". Now, even if there is no direct evidence in Smith's text of these diverging rates, such an assumption must be considered as implicit or necessary for supporting the internal consistency, as well as the inter-temporal validity, of his system of thought in so far as it is focused on that "uniform, constant and uninterrupted effort of every man to better his condition". It must however be noted that the success of this effort cannot materialize if one believes that, even in modern societies, technical progress, whether in its neutral or capital-saving forms, is not strong enough for keeping the increase of those funds above a given increase of population. And it cannot occur for even a stronger reason if one believes, in Smith's footsteps, that the accumulation of capital is "almost always" needed for increasing the productivity, rather than the employment, of labor ( $W N$, II.iii.32). Which implies that, net of the benefits resulting from the simpler forms of technical progress and given the obstacles provided by the possibility of diminishing returns, the process of capital accumulation cannot provide a continuous increase of national wealth such as to overcome a continuous increase of population. Hence the spread of the preventive checks (to use a term introduced by Malthus with exclusive regard to the postponement of marriages and of sexual intercourses) so widely practiced in modern times under the synthetic term of birth control. The implementation of this new approach to the reproduction of human beings has made it possible to turn the population of modern societies into a variable depending on the actual or expected level of income per head; i.e. into something that was either impossible or unacceptable in past centuries when infant mortality and life expectancy were so far away from what they are today.

It can however be added that the inverse relationship between income per head and human fertility is somewhat admitted by Smith himself when comparing the "half-starved Highland 
woman", mentioned above, with the "pampered fine lady" who is "generally exhausted by two or three" children ( $W N$, I.viii.37). This inverse relationship can indeed be developed further if we resort to an inter-temporal comparison between the fertility rates and living standards experienced by the "inferior ranks of people" in Smith's own times and those experienced by the same ranks of people in the more advanced economies of our times. This comparison would help us to adjust Smith's arguments on the "liberal reward of labour" as the necessary effect of increasing wealth ( $W N$, I.vi.27) as well as the cause of an increasing population ( $W N$, I.vi.42). For it is true that, after noting that the habits of these ranks descend from the higher mortality of their children, Smith fails to develop his argument as he would have done if he simply were living in our times. But in this case he would also recognize what the reproductive behavior of the "common people" has become, once the (nearly zero) mortality of children experienced today is considered in conjunction with the quantity and quality of the wage goods exchanged today for the labor of the "inferior ranks of people" beyond the levels reached by the "people of fashion" in Smith's own times ${ }^{20}$.

${ }^{20}$ Concerning Malthus' theory of population, it is true that this theory was focused, in its first version, on population as an exogenous variable (in the sense that in the rude state of society diseases, cannibalism, infanticide, famine and war were responsible for cutting its geometric progression) and, in the following versions, on population as an endogenous variable regulated by preventive checks (see Malthus, 1826 [1986, I, chaps. I-II]). But it is widely known that in modern societies these checks, far from descending from a restraint either from marriage or from sexual intercourse, more simply consist in the adoption of birth control techniques as new forms of "moral restraint". It is here impossible to dwell on the economics of population as developed in recent times with regard to family planning, birth rates, death rates, contraception methods, etc. in the context (mentioned in a footnote bove) of the increasing working age and life expectancy of modern times. On Malthus' changing views within his own theory of population, see Gilbert (1980) and, in a wider context, Hollander (1997 and, more particularly, chaps. 1, 5, 18.v and 19.iv). See also 
5. From self-interest and competition, capital accumulation and population growth to the longrun increase of wages

We have noted above that the expression "increase of stock" is introduced at the end of chapter VIII, Book I, in anticipation of, and as a link with, chapter III, Book II, of $W N$. This is announced by Smith himself when, in the middle of chapter IX, Of the Profits of Stock, Book I, he returns to "the connection between the increase of stock and that of industry" by stressing that this connection "will be explained more fully" in Book II (WN, I.ix.11). Now it must be noted that the term industry is used in this Book not only in the sense, adopted in Book I and discussed above, of the industriousness of common people; but also in the more advanced direction of the increasing productivity of labor (once the length of the working day is given) which results (up to a certain point) from the division of labor (as discussed in Book I) and (from that point onwards) from the accumulation of capital (as discussed in Book II). Although Smith is not so explicit, when he comes to the latter topic, in recognizing the two forms of accumulation mentioned above as capital widening and capital deepening, yet he provides some hints on this distinction by mentioning two circumstances which reinforce each other in promoting a continuous increase in the productivity of labor. One has already been mentioned with regard to the substitution of machinery for labor as a reaction to increasing wages (and to the corresponding fall of profits). The other occurs when technical progress re-enters Smith's arguments either in the forms of neutral technical progress (as in the simplified example of the boy "who loved to play with his companions", WN, I.i.8); or in the capital-saving forms (as when "the same number of workmen" are able to perform "an equal quantity of work with cheaper and simpler machinery," $W N$, II.ii.7); or in the more advanced capital-using forms (which, as noted above, are thought by Smith to prevail over the other forms).

Cunningham Wood (1986, 4 Vols., and, more particularly, Vol. II, chaps. 33-36). For a more specific treatment of these issues, see, just to begin with, Lewis (1954), Spengler (1976), Wrigley (1988), Strulik and Weisdorf (2008). 
Now, if Smith's advanced arguments on capital accumulation are considered in conjunction with his simpler arguments on technical progress, it becomes possible to highlight the impact that all these arguments imply, once they are re-formulated and adjusted in the sense suggested above, in terms of the future of wages. It is worth recalling that, while one of these arguments concerns the increasing demand for labor associated with shifts of the wage-profit inverse relationship, the other concerns the rate of increase of population (labor supply) as falling short of the rate of increase of the demand for it; and, finally, the third concerns the process of capital accumulation as taking place in the context of a permanent competition between "masters and manufacturers". Now, if these arguments are considered in relation to each other, it is possible to conclude that their unified impact will just involve a long-run increase of the demand for labor in excess of its supply, the unavoidable outcome of this impact being a long-run increase of wages ${ }^{21}$. This outcome is

${ }^{21}$ This is consistent with Smith's statement that, in the long-run context of an increasing demand for labor, "luxury extends itself even to the lowest ranks of the people", and, more particularly, to the "fair sex" (in which case it "seems always to weaken, and frequently to destroy altogether, the powers of generation") ( $W N$, I.viii.37-38). This view reappears in a number of classical and modern authors. See, for instance, Blaug's observation that, as an economy develops, "the luxuries of one generation become the decencies of the next and, eventually, the necessaries of subsequent generations" (1985, p. 72) along with Ricardo's own remark that "many of the conveniences now enjoyed in an English cottage, would have been thought luxuries at an earlier period of our history" (Principles, p. 97). Ricardo, it must however be noted, restricts this argument to differences between, and variations of, the "habits and customs" of the people, thereby leaving in the dark the systematic causes of these differences and variations. A similar approach reappears in a number of modern writers. See, for instance, Eltis' argument against the idea of the iron law of wages along with his diverging conclusion that "a model that predicted an indefinite continuation of growth would not be Smith's" (1984, p.89 and p. 70). See, in support of this view, Brewer (2010, chap. 2 , 
unavoidable in spite of the fact that the self-interest of "masters and manufacturers" is such that they will not welcome, and are usually combined against, such an increase.

This outcome, it must now be noted, bears some similarity with the apparently different one discussed by Smith when defending the principle of free trade against the restraints upon importation and the encouragement to exportation advocated by Mercantilists ${ }^{22}$. However different the subject of international trade may be from the subject of how the long-run demand for labor will interact with its supply, it is nonetheless possible to conclude that the rise of wages contemplated by the three arguments above may be viewed as one of the "many other cases" in which individuals are led by an invisible hand to promote an end which was no part of their intentions $(W N \text {, IV.ii.9 })^{23}$. Which implies the further conclusion that, when the conditions assumed in these arguments are met, p. 28 and note 23) and, against it, Aspromourgos (2009, 2010). See also Stigler (1976) who, speaking of the "successes that Smith should have achieved, but did not", mentions his "rejection of the subsistence theory of wages".

${ }^{22}$ This is done by Smith in two different steps. First, when announcing the principle that "every individual is continually exerting himself to find out the most advantageous employment for whatever capital he can command. It is his own advantage, indeed, and not that of the society, which he has in view. But the study of his own advantage naturally, or rather necessarily, leads him to prefer that employment which is most advantageous to the society ( $W N$, IV.ii.4). And, afterwards, when applying this principle to the realm of international trade where it happens that " by preferring the support of domestic to that of foreign industry, he [i.e. every individual] intends only his own security; and by directing that industry in such a manner as its produce may be of the greatest value, he intends only his own gain, and he is in this, as in many other cases, led by an invisible hand to promote an end which was no part of his intention" ( $W N$, IV.ii.9).

${ }^{23}$ For an overview of at least some of the numerous interpretations of this process, see, for instance, Eatwell, Milgate and Newman (1989), Rotschild (2001) and Samuels (2011). 
the process of capital accumulation, whether associated with neutral or more advanced forms of technical progress (as is usually the case beyond a certain limit and in the capital-deepening context of our age), presents itself as the ultimate force that can promote a long-run increase of wages ${ }^{24}$.

\section{Concluding remarks}

Following Schumpeter's view of the relation between $T M S$ and $W N$ as "blocks cut out from a larger systematic whole" (1956, p. 141), we have focused above on the block of market exchanges, starting from the nature of, and the possible conflict between, the principles of self-interest and competition that lie behind the behavior of the individuals engaged in these exchanges. After examining the role played by these principles in determining the value of labor in a demand-and-

${ }^{24}$ The difference between increasing and high wages is crucial for understanding an important difference between an "advancing" and a "stationary" economy. For the latter kind of economy may experience a high level of wages, though not for long periods of time, while it is only in the former kind that wages (whether high or low) undergo a continuous increase. This issue is missing in Waterman's argument (2012) that the accumulation of capital, as "Smith's prescription" for high wages, is neither a necessary nor a sufficient condition of them. For this argument is based on the silent assumption that the accumulation of capital fails to result in an increasing demand for labor even when technical progress, whether embodied or not, can neutralize the increasing cost per unit of output resulting from increasing wages. A similar issue has been raised by Samuelson (1977) along a different line of reconstruction of Smith's thought in the context of his well-known exclamation "hats off, I say, to Adam Smith". But it is weakened by his misleading view of Smith's "demographic hypothesis that population explodes" (an hypothesis that rather belongs to Malthus the Younger) along with his own view of the "cheerful" state sinking into "Smith's long-run $d u l l$ state" as a result of the "constraint of scarce good land" (a state, however, which prevails in Ricardo's and Malthus', rather than in Smith's, views of a growing economy). 
supply context, we have moved to the manifold link between chapter VIII, Book I, and chapter III, Book II, of $W N$. This link has been brought to the fore by focusing, first, on Smith's concept of “industry" as distinct from his more advanced concept of "productive powers of labour"; and, later on, on the accumulation of capital as the main force which, associated with technical progress, can support and elevate these powers from period to period. In order to prove how the increase in these powers may be turned into a long-run increase of wages, we have focused above on the principle of demand for, and supply of, labor in the dynamic context of a continuous process of capital accumulation and population growth. We have accordingly argued that, in spite of Smith's inclination to assume some equality between the growth of the demand for, and of the supply of, labor (population) in a growing economy, his theory of population rather needs an explicit adjustment for it to be consistent with the possibility of a long-run increase of wages. This adjustment calls for an introduction into Smith's system of thought of the assumption (supported as it is in modern societies by the widespread use of birth control techniques) of the long-run supply of labor (population) increasing at a lower rate than the long-run demand for it. This dynamic context includes one of the "many other cases" in which the invisible hand reappears as just one of what are called today the "unintended consequences of human action". The final conclusion of the paper is that this particular consequence corresponds to a repeated increase in the "liberal reward of labor" (within one country or across different countries) as the ultimate result of the "uniform, constant, and uninterrupted effort of every man to better his condition". This repeated increase is silently promoted from period to period by the process of capital accumulation if this takes place under conditions of competition within the markets not only of labor (as living labor) but also of commodities as products of labor (or as different forms of dead labor). Hence the difference between the reproduction of laborers and the reproduction of commodities. For it is the employment of capital and the expectation of profit that lie behind the decisions of individuals to put in motion the production and reproduction of commodities, while it is a completely different principle that lies behind their very different decisions to put in motion the production (to use Smith's famous term) 
and reproduction (to use a more appropriate term) of human beings, including laborers as suppliers of the ultimate resource for the production and reproduction of national wealth.

\section{REFERENCES}

Aspromourgos, Tony. 2009. The Science of Wealth: Adam Smith and the Framing of Political Economy, London: Routledge

Aspromourgos, Tony. 2010. “'Universal Opulence': Adam Smith on technical progress and real wages", The European Journal of the History of Economic Thought, 17 (5): 1169-1182

Berry, Christopher J., Paganelli ,Maria P. and Smith, Craig (eds.) 2013. The Oxford Handbook of Adam Smith, Oxford; Oxford University Press

Blaug, Mark. 1985 . Economic Theory in Retrospect, Cambridge: Cambridge University Press

Bowley, Marian. 1975. "Some Aspects of the Treatment of Capital in The Wealth of Nations", in A. S. Skinner and T. Wilson (eds.), pp. 361-376

Brewer, Anthony. 2010. The Making of the Classical Theory of Economic Growth, London and New York: Routledge

Cannan, Edwin A. [1917] 1967. A History of the Theories of Production and Distribution from 1776 to 1848 , New York: A. M. Kelly

Cantillon, Richard. [1755] 1964. Essai sur la Nature du Commerce en Général, edited by H. Higgs, New York: A. M. Kelley

Cunningham Wood, John. (ed.) 1984. Adam Smith: Critical Assessments, London: Croom Helm, 4 Vols.

Cunningham Wood, John. (ed.) 1986. Thomas Robert Malthus: Critical Assessments, London: Croom Helm, 4 Vols.

Eatwel John, Milgate Murray and Newman Peter (eds.) 1989. The Invisible Hand, London: Macmillan

Eltis, Walter A.. 1984, The Classical Theory of Economic Growth, London: Macmillan

Evensky, Jerry. 2005. Adam Smith's Moral Philosophy, Cambridge: Cambridge University Press

Fleischacker, Samuel. 2004. On Adam Smith's Wealth of Nations: a Philosophical Companion, Princeton: Princeton University Press

Gilbert, Geoffrey. 1980. "Economic Growth and the poor in Malthus' Essay on Population", History of Political Economy, 12 (1): 83-96

Haakonssen, Knud (ed.). 2006. The Cambridge Companion to Adam Smith, Cambridge: Cambridge University Press

Hawtrey, Ralph G. 1952. Capital and Employment, London: Longmans, Green and Co.

Heath, Eugne. 2013. "Adam Smith and Self-Interest”, in Berry C. J., Paganelli M. P. and Smith C., (eds) 2013, pp. 241-264

Hollander, Samuel. 1973. The Economics of Adam Smith, Toronto: University of Toronto Press

Hollander, Samuel. 1977, “Adam Smith and the Self-Interest Axiom”, Journal of Law and Economics, 20 (1): 133-152 
Hollander, Samuel. 1997. The Economics of Thomas Robert Malthus, Toronto: University of Toronto Press

Hollander, Samuel. 2019. "Ricardo on Machinery", Journal of Economic Perspectives, 33 (2): 229242

Kurz, Heinz D. 2010. "Technical progress, capital accumulation and income distribution in Classical economics: Adam Smith, David Ricardo and Karl Marx", The European Journal of the History of Economic Thought, 17 (5): 1183-1222

Lewis, Arthur. 1954. "Economic Development with Unlimited Supplies of Labour", The Manchester School, 22 (2): 139-191

Malthus, Thomas R. [1826] 1986. An Essay on the Principle of Population, Sixth edition, in E. A. Wigley and D. Souden (eds), The Works of Thomas Robert Malthus, London: William Pickering, Vol. 2

Malthus, Thomas R,. [1836] 1986. Principles of Political Economy, in E. A. Wigley and D. Souden (eds), The Works of Thomas Robert Malthus, London: William Pickering, Vols. 5-6

Meacci, Ferdinando. 2006. "The competition-of-capitals doctrine and the wage-profit relationship", in Neri Salvadori (ed.), Economic Growth and Distribution: On the Nature and Causes of the Wealth of Nations, Cheltenham: E. Elgar, pp. 58-74.

Meacci, Ferdinando. 2012. “On Adam Smith's Ambiguities on Value and Wealth", History of Political Economy, 44 (4): 663-689.

Meacci, Ferdinando. 2017. “On Adam Smith's 'Original Error respecting Value'”, Adam Smith Review, 10,:286-301.

Meacci, Ferdinando and Ferlito, Carmelo. 2018. "The classical roots of the Austrian theory of capital and entrepreneurship", The Review of Austrian Economics, 31: 315-339

Montes, Leonidas. 2004. Adam Smith in Context. A Critical Reassessment of Some Central Components of his Thought, New York: Palgrave Macmillan

Montes, Leonidas. and Schliesser, Erich (eds.). 2006. New Voices on Adam Smith, London:

Routledge

O' Donnell, Rory. 1990. Adam Smith's Theory of Value and Distribution: a Reappraisal, London: Macmillan

O' Driscoll, Gerald P. (ed.) 1979. Adam Smith and Modern Political Economy: Bicentennial Essays on The Wealth of Nations, Ames: The Iowa State University Press.

Otteson, James R. 2002. Adam Smith's Marketplace of Life, Cambridge: Cambridge University Press

Paganelli Maria P. 2008. "The Adam Smith Problem in Reverse: Self-Interest in The Wealth of Nations and The Theory of Moral Sentiments", History of Political Economy, 40 (2): 365-382

Raphael, David D. and Alexander L. Macfie, 1976. "Introduction”, in Smith [1759] 1976, pp. 1-52

Ricardo, David [1821] 1951. On the Principles of Political Economy and Taxation, in P. Sraffa (ed.), 1951-1973, Vol. I

Rosenberg, Nathan. 1975. “Adam Smith on Profits. Paradox Lost and Regained”, in Skinner and Wilson (eds.), pp. 377-389

Rothschild, Emma. 2001. Economic Sentiments: Adam Smith, Condorcet and the Enlightenment, Cambridge, MA: Harvard University Press 
Samuels, Warren J. 2011. Erasing the Invisible Hand. Essays on an Elusive and Misused Concept in Economics, Cambridge: Cambridge University Press

Samuelson, Paul A. 1977. “A Modern Theorist's Vindication of Adam Smith”, American Economic Review, 67 (1): $42-49$

Sen, Amartya K. 2011. "Uses and Abuses of Adam Smith", History of Political Economy, 43 (2): 257-271

Sinha, Ajit. 2010, "In defence of Adam Smith's theory of value", The European Journal of the History of Economic Thought, 17 (1): 29-48

Skinner, Andrew S. (ed.) 1996. A System of Social Science: Papers Relating to Adam Smith, Oxford: Clarendon

Skinner, Andrew S. and Wilson, Thomas (eds.). 1975. Essays on Adam Smith, Oxford: Clarendon Press

Smith, Adam. [1759] 1976. The Theory of Moral Sentiments, edited by D. D. Raphael and A. L. Macfie, Indianapolis: Liberty Classics

Smith, Adam. [1776] 1976. An Inquiry into the Nature and Causes of the Wealth of Nations, edited by R. H. Campbell and A. S. Skinner, Indianapolis: Liberty Classics

Smith, Adam. [1776] 1978. Lectures on Jurisprudence, edited by R. L. Meek, D. D. Raphael and P. G. Stein, Indianapolis: Liberty Classics

Spengler, Joseph J. (1976), "Adam Smith on Population Growth and Economic Development", Population and Development Review, 2 (2): 167-180

Sraffa, Piero (ed.) (1951-1973). The Works and Correspondence of David Ricardo, Cambridge: Cambridge University Press, 11 Vols.

Stigler, George J. 1971. "Smith's Travels on the Ship of State", History of Political Economy, 265-277; in Skinner and Wilson (eds.), 1975, pp. 237-246.

Stigler, Georg J. 1976. "The Successes and Failures of Professor Smith", Journal of Political Economy, 84 (6): 1199-213

Strulik, Holger and Weisdorf, Jacob. 2008. "Population, food, and knowledge: a simple unified growth theory", Journal of Economic Growth, 13 (3): 195-216

Waterman, Anthony M. C. 2012."Adam Smith and Malthus on High Wages”, The European Journal of the History of Economic Thought, 19: 409-429

Wicksell, Knut. 1967 (1934). Lectures on Political Economy, Vol. I, London: Routledge

Wilson, Thomas. 1976. "Sympathy and Self-Interest", in Wilson T. and A. S. Skinner (eds.), 1976, pp. 73-99, and comments, pp. 99-112

Wilson, Thomas and Skinner Andrew S. (eds.). 1976. The Market and the State. Essays in Honour of Adam Smith, Oxford: Clarendon Press

Wrigley, Edward A. 1988. "The Limits to Growth: Malthus and the Classical Economists", Population and Development Review, 14: 30-48

Young, Allyn A. 1928. "Increasing Returns and Economic Progress", Economic Journal, 38, 52742.

Young, Jeffrey T. (ed.). 2009. Elgar Companion to Adam Smith, Cheltenham: Edward Elgar 